\title{
Workshop on Implementation of Learning on Disability Teaching in the Era of Industrial Revolution 4.0
}

\author{
Adi Rahadian1, Ervan Kastrena², Aziz Amirullah³, Firdaus Hendry Prabowo4, Andi Kurniawan \\ Pratama $^{5}$, Muhamad Syamsul Taufik ${ }^{6}$, Asep Ramdan Afriyuandi ${ }^{7}$ \\ 1,2,3,4,5,6,7 Universitas Suryakancana \\ Email:1adira@unsur.ac.id, 2ervankastrena@unsur.ac.id, 3aziz@unsur.ac.id, \\ 4firdaus_hendri@unsur.ac.id, 5andikpratama@unsur.ac.id, ${ }^{6}$ syamsul@unsur.ac.id, \\ 7arafriyuandi@unsur.ac.id

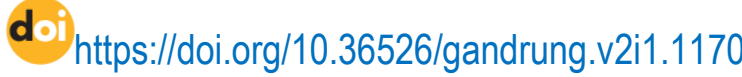

\begin{abstract}
In this study looking for how much the level of teacher ability in the development of physical education As for the stages of research as follows: (1) Conduct initial identification and analysis of the needs of the object and location of research and conduct preliminary studies, and also literature studies relating to research, (2) Arranging program plans regularly, (3) Arranging instructional, books or activity evaluation tools, (4) Developing research instruments to reveal the ability of physical education teachers in developing Physical Education learning (5) Conducting small group trials to Physical Education teachers; and (6) conducting field trials on physical education teachers. So the conclusion of this research is the experience factor which consists of teaching experience of children with special needs and contact experience with children with special needs. Third, knowledge factors consisting of teacher education background, training, knowledge, and teacher learning needs. Fourth, educational environment factors consisting of resource support, parent and family support, and the school system.
\end{abstract}

Keywords: Education, Physical Education Resources, Students

Pendahuluan

Proses pendidikan di sekolah, mengutamakan kegiatan belajar para siswa. Pendidikan itu sendiri dapat diartikan sebagai usaha sadar yang dilakukan oleh setiap individu untuk mengembangkan potensi yang dimilikinya agar berkembang secara maksimal. Hal ini berarti bahwa melalui pendidikan, siswa diharapkan memiliki nilai-nilai yang berguna bagi diri sendiri, keluarga, masyarakat, dan bangsa. Pembelajaran yang inovatif dan kreatif diharapkan dapat mengelola dan mengembangkan komponen pembelajaran dalam suatu desain yang terencana dengan memperhatikan kondisi aktual dari unsurunsur penunjang dalam implementasi pembelajaran yang akan dilakukan. Pendidikan jasmani pada hakekatnya meningkatkan derajat sehat dinamis yang merupakan wujud dari kebugaran jasmani, yang akan menjadi dasar terwujudnya rohani dan sosial yang sehat.

Olahraga sebagai kegiatan pemulihan keadaaan fisik (jasmani) memiliki peranan yang sangat penting untuk meningkatkan kebugaran jasmani yang merupakan upaya membina kesehatan yang bersifat aktif. Kemudian menurut (Yuniarto et al., 2018, p. 1) olahraga adalah suatu kegiatan yang hampir semua orang pernah melakukan sepanjang hidupnya, baik yang dilakukan secara profesional dengan 
GANDRUNG: Jurnal Pengabdian Kepada Masyarakat ISSN: 2721-6136 (Online)

latihan dan jadwal pertandingan yang ketat, maupun olahraga yang dilakukan sekedar sebagai hobi pengisi waktu luang.

Tugas yang paling utama dalam menyelenggarakan pendidikan jasmani adalah bagaimana membantu para siswa untuk dapat menjalani proses pertumbuhan dan perkembangan secara optimal baik secara fisik, motorik, mental dan sosial. Belajar menurut (Wijayanto et al., n.d., p. 29) adalah "perubahan perilaku sebagai hasil dari pengalaman, bukan karena pengaruh faktor keturunan atau kematangan." Perubahan perilaku yang diharapkan dari belajar bersifat melekat secara permanen. Proses belajar itu sendiri tidak dapat diamati secara langsung. Namun demikian keterlaksanaannya hanya dapat ditafsirkan berdasarkan perilaku nyata yang diamati. Perubahan-perubahan perilaku akan terjadi melalui proses mengajar yang disengaja, yang kebetulan, tidak disengaja, bahkan mungkin karena seseorang melakukan kesalahan-kesalahan belajar. Menurut (Fathurrahman et al., 2019) penyampaian materi yang dilakukan selama ini dalam proses mengajar hanya mempraktikkan sendiri contoh gerakan yang akan dilakukan, selanjutnya siswa mengikuti atau mencontoh apa yang disampaikan sehingga Perlu adanya inovasi yang di kembangkan sebab (Sumantri \& Neldi, 2019, p. 2) pembelajaran pendidikan jasmani olahraga dan kesehatan guru harus mempunyai kompetensi yang mendukung dalam proses pembelajaran yakni kompetensi Pedagogik, kompetensi kepribadian, kompetensi sosial, kompetensi profesional, keempat kompetensi tersebut yang harus dimiliki oleh seorang guru dalam proses pembelajaran pendidikan jasmani olahraga.

Pendidikan jasmani pada hakekatnya menurut (Suherman 2009:5) dalam (Anjar et al., 2020) mempunyai tiga kata kunci, yaitu 1) pendidikan (education), yang direfleksikan dengan kompetensi yang ingin diraih siswa, 2) melalui dan tentang (through and of), sebagai kata sambung yang menggambarkan keeratan hubungan yang dinyatakan dengan berhubungan langsung dan tidak langsung, dan 3) gerak (movement), merupakan bahan kajian sebagaimana tertera dalam kurikulum pendidikan jasmani.

Dikemukakan lebih lanjut oleh (Adi \& Muhamad, 2020, p. 1) bahwa: Keberhasilan mengajar tidak hanya sekedar memelihara siswa aktif berolahraga, senang, dan segar pada saat dan setelah melakukan pengajaran. Lebih dari itu, keberhasilan mengajar mengandung arti siswa belajar dan mengembangkan sikap positif, guru mendapat kepuasan dari mengajarnya, dan program penjas yang sudah diberikan sesuai dengan semua tujuan sekolah.

\section{Metode}

Tahapan Pengabdian Pada Workshop di SLB Bina Asih Cianjur ini \, Adapun tahapan-tahapan Pengabdian sebagai berikut: 1.Melakukan identifikasi awal beserta analisa kebutuhan terhadap objek 
GANDRUNG: Jurnal Pengabdian Kepada Masyarakat ISSN: 2721-6136 (Online)

dan lokasi Pengabdian serta melakukan studi pendahuluan, dan juga studi literatur yang berkaitan dengan Pengabdian ini; 2.Menyusun rencana program Pengabdian secara berkala; 3.Menyusun instruksional, buku atau alat evaluasi kegiatan; 4.Menyusun instrumen Pengabdian untuk mengungkap kemampuan guru penjas dalam pengembangan pembelajaran penjas; 5.Melakukan uji coba kelompok kecil kepada guru penjas; dan 6.Melakukan uji coba lapangan kepada guru penjas. Lokasi Pengabdian yang dilaksanakan di SLB Bina Asih, Joglo, Cianjur, Kegiatan mengajar di laksanakan di SLB ABC Bina Bangsa Karang tengah Cianjur yang dilakukan seminggu sekali dan tiap hari materi pembelajarannya berbeda-beda agar anak-anak tidak merasa jenuh. kami melaksanakan proses pembelajaran dari mulai pada bulan Februari s.d Juli 2019.

Peserta Didik Siswa/i yang terdaftar di SLB ABC Bina Bangsa.Peubah yang diamati Tingkat Kemampuan Guru Penjas dalam Pengembangan Pembelajaran Penjas Pengabdian dengan Pendekatan research \& development dilakukan dalam pengembangan produk yang dapat dimanfaatkan untuk kepentingan peningkatan kualitas sumber daya manusia (SDM), seperti melalui pendidikan dan pelatihan. Penggunaan produk yang telah divalidasi melalui Pengabdian ini dapat menghasilkan luaran pembelajaran yang sesuai dengan tujuan yang dicapai. Atas dasar untuk menjawab permasalahan melalui pengujian dan kesimpulan yang dihasilkan adalah jawaban dari permasalahan yang diajukan dengan verifikasi menggunakan data empirik dari pengamatan (observasi). Dengan demikian hasil dalam penelitian ini dapat dimanfaatkan sesuai dengan fungsi dan kepentingannya untuk direkomemdasikan serta diilmplikasikan.

\section{Model Instrumen Pengabdian Masyarakat}

Pengabdian ini jenis Penelitian $R \& D$ research \& development dengan model siklus dari action research. Pada Pengabdian ini menggunakan instrumen observasi berupa pertanyaan secara tertulis yang diberikan kepada responden untuk diisi sesuai dengan keadaan sesungguhnya. Rancangan Pengabdian Jenis Penelitian, Penelitian research \& development adalah suatu penelitian yang bertujuan untuk mengembangkan suatu produk baru atau menyempurnakan produk yang telah ada. Istilah produk bisa berarti perangkat keras (hardware) seperti alat pelontar bola, modul, instrumen, alat bantu pembelajaran atau perangkat lunak (software) seperti model pembelajaran interaktif, model bimbingan dan sebagainya Pengabdian dengan Pendekatan Penelitian pengembangan umumnya bersifat siklus, yang diawali dengan adanya kebutuhan, kebutuhan tersebut dapat diselesaikan dengan pengembangan produk, dan untuk menghasilkan produk terpercaya perlu dilakukan pengujian beberapa kali. Pengembangan Model Dick \& Carey (Gall et al., 2003, p. 79) sebagai berikut: 1.Analisis kebutuhan untuk 
GANDRUNG: Jurnal Pengabdian Kepada Masyarakat ISSN: 2721-6136 (Online)

merumuskan tujuan pembelajaran dengan tepat; 2.Analisis pembelajaran untuk melaksanakan pembelajaran secara efektif; 3.Analisis konteks yang berkaitan dengan pembelajaran; 4.Tentukan tujuan pembelajaran untuk mencapai pembelajaran; 5.Menyususn instrumen untuk mengukur keberhasilan pembelajaran; 6.Pengembangan starategi (persiapan, praktik, umpan balik, evaluasi, dan tindak lanjut) pembelajaran untuk dapat mencapai tujuan 7.Pengembangan materi pembelajaran yang mencakup bentuk materi pembelajaran; dan 8.Menyusun dan melakukan evaluasi formatif yang diarahkan pada perbaikan model pembelajaran (one to one evaluation, group evaluation, dan field evaluation). 9.Melakukan revisi (dari data formatif dan sumatif untuk memperbaiki model pembelajaran)

Teknik Pengumpulan dan Analisis Data Pada Pengabdian ini adalah Teknik pengumpulan data yang digunakan dalam penelitian ini adalah pengamatan (observasi), wawancara, dokumen, dan kuesioner berdasarkan triangulasi dengan analisis data kualitatif (Maksum, 2012:86). Observasi dilakukan pada setiap tahapn penelitian, mulai tahap pra survey, tahap pengembangan sampai tahap uji coba yang lebih luas. Wawancara dan kuesioner digunakan untuk mengumpulkan data khususnya pada studi pendahuluan yaitu menjawab pertanyaan penelitian yang berhubungan dengan perencanaan dan pelaksanaan pembelajaran penjas.

Teknik analisis data kualitatif menurut (Maksum 2012:86-87) dalam (Wisman, 2017) didasarkan pada reduksi data, displai data, dan verifikasi data melalui tahapan-tahapan, sebagai berikut: 1.Data hasil wawancara atau observasi ditranskrip dalam bentuk yang mudah dibaca; 2.Transkrip yang telah dipastikan akuransinya dibaca dengan cermat dan berulang-ulang untuk memahami konsep atau tema yang menjadi fokus penelitian; 3.Mengidentifikasi mana dari serangkaian peristiwa hasil wawancara atau observasi yang merupakan perwujudan dari konsep atau tema tersebut; 4.Menemukan kata kunci dari peristiwa-peristiwa yang teridentifikasi; 5.Melakukan interpretasi kata kunci berdasaran rujukan yang relevan; dan 6.Setelah melakukan serangkaian proses di atas untuk tiap-tiap transkrip, kemudian disusun tema-tema dan kategori-kategori sehingga menampilkan pola-pola antar kategori tersebut.

\section{Hasil dan Diskusi}

Berdasarkan fakta di lapangan yang dilaksanakan Pengabdian ini,berbagai dan tingkatan pemahaman guru terhadap pendidikan inklusi yang ditunjukan keempat subjek ditemukan berbagai persamaan dan perbedaan. Berdasarkan faktor pengalaman terdapat faktor latar belakang guru yang menunjukan alasan subjek menjadi guru di sekolah luar biasa (SLB) Bina Asih Cianjur. Berdasarkan faktor ini ditemukan tiga perbedaan, pertama terdapat guru yang bekerja di biasa (SLB) Bina Asih Cianjur karena penempatan yang diberikan oleh dinas pendidikan karena subjek adalah seorang guru yang 
GANDRUNG: Jurnal Pengabdian Kepada Masyarakat ISSN: 2721-6136 (Online)

memiliki latar belakang Pendidikan Guru, kedua, karena kebutuhan ekonomi dan ingin mencari pengalaman melihat bahwa dukungan finansial di sekolah masih kurang, ketiga, karena rasa ingin tahu terhadap penanganan anak berkebutuhan khusus memiliki pengalaman dengan anak berkebutuhan khusus jauh sebelum bekerja di biasa (SLB) Bina Asih Cianjur. Faktor pandangan terhadap anak berkebutuhan khusus menunjukan bahwa semua subjek merasa anak berkebutuhan khusus sulit untuk ditangani, sehingga hal ini mempengaruhi pandangan terhadap tingkat kelas dan layanan kelas untuk anak berkebutuhan khusus.

Guru khusus tidak pernah mengungkapkan bahwa anak berkebutuhan khusus lebih baik ditempatkan di layanan kelas khusus atau pra klasikal. Guru khusus dan guru reguler perempuan lebih memiliki kedekatan terhadap anak berkebutuhan khusus. Mereka lebih menerima kehadiran anak berkebutuhan khusus dan lebih memiliki empati kepada anak berkebutuhan khusus. Empati yang ditunjukan oleh kedua subjek ini berupa perasaan kasihan dan senang terhadap anak berkebutuhan khusus. Guru khusus dan guru reguler laki-laki lebih bersikap biasa terhadap anak berkebutuhan khusus dan menjaga hubungan dengan anak berkebutuhan khusus sebatas hubungan antara guru dan murid. Keyakinan yang dimiliki subjek memunculkan hasil yang berbeda-beda. Guru khusus lebih yakin pada cara pemenuhan kebutuhan anak berkebutuhan khusus harus disesuaikan pada kebutuhan dan kondisi anak yang beragam. Faktor pengetahuan sangat berperan dalam membentuk sikap guru ini, dan menariknya seluruh subjek memiliki keinginan untuk mendalami pemahaman mengenai anak berkebutuhan khusus, baik melalui belajar dari rekan kerja yang lebih senior, melalui pelatihan, maupun melalui mendaftar pada sebuah universitas untuk melanjutkan pendidikan di bidang Pendidikan Luar Biasa.

Pandangan sosio-politik keempat subjek lebih mengarah pada pandangan terhadap dukungan pemerintah. Keempat subjek melihat bahwa program pendidikan inklusi dari pemerintah sangat bagus bagi kehidupan anak berkebutuhan khusus. Namun, subjek lebih melihat bahwa anak berkebutuhan khusus lebih baik diberikan program lain yang lebih sesuai karena merasa anak berkebutuhan khusus sulit untuk ditangani. Lebih lanjut lagi, subjek merasa dukungan sumber daya dari pemerintah untuk sekolah masih kurang sehingga menghambat subjek untuk memenuhi kebutuhan anak berkebutuhan khusus. Pendapat subjek tersebut memang berkaitan dengan sumber daya yang tersedia di SLB Bina Asih Cianjur. Fasilitas dan dana yangvtersedia memang bisa dikatakan masih kurang menunjang program belajar dan mengajar bagi seluruh siswa. Keempat subjek melihat dukungan rekan kerja sangat penting karena melalui sharing masalah dengan rekan kerja, keempat subjek dapat menemukan solusi dalam menangani anak berkebutuhan khusus serta dapat menurunkan tingkat jenuh yang didapat 
GANDRUNG: Jurnal Pengabdian Kepada Masyarakat ISSN: 2721-6136 (Online)

selama mengajar. Dukungan dan kerjasama dari orang tua dan keluarga siswa pun tidak kalah penting bagi keempat subjek, karena melalui orang tua dan keluarga subjek dapat lebih memahami kebutuhan anak berkebutuhan khusus dan melalui kerjasama orang tua dan keluarga perkembangan anak berkebutuhan khusus dapat dipertahankan. Sistem sekolah merupakan faktor yang menarik dalam membentuk sikap subjek terhadap pendidikan inklusi.

Foto Pengabdian Workshop di SLB Bina Asih Cianjur yang di laksanakan :
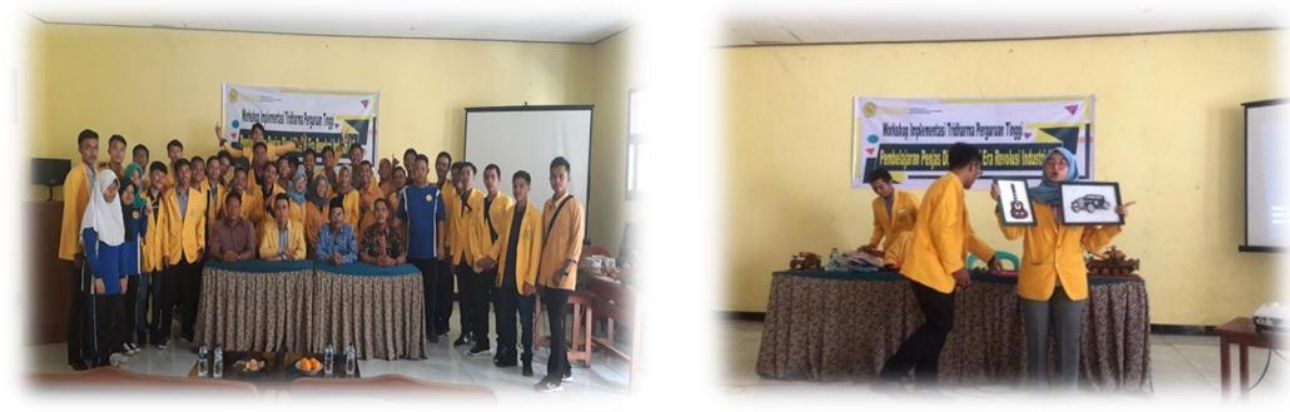

Gambar 1. Foto Bersama Peserta dan Guru pada Pemberian Materi Workshop di SLB Bina Asih Cianjur

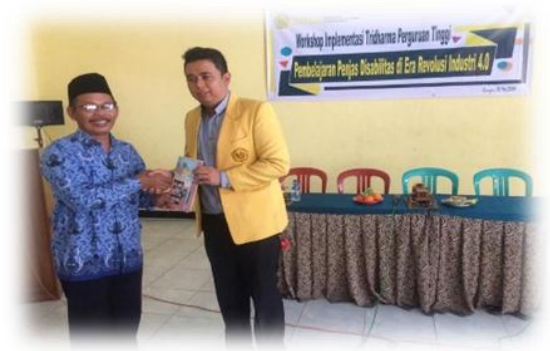

Gambar 2 .Pemberian Penghargaan Workshop di SLB Bina Asih Cianjur

Sistem sekolah di SLB Bina Asih Cianjur dalah memenuhi kebutuhan anak berkebutuhan khusus melalui penempatan anak ke dalam berbagai layanan kelas yang tersedia. Layanan kelas tersebut terdiri dari kelas inklusi penuh, kelas pra klasikal, dan kelas khusus. Ada beberapa Faktor yang mengetahui hasil penelitian ini bahwa dukungan nya yaitu (kesesuaian disiplin ilmu 90\%), kebutuhan ekonomo (87\%) Pandangan para subjek tersebut juga dipengaruhi oleh tipe guru yang mereka miliki. 
GANDRUNG: Jurnal Pengabdian Kepada Masyarakat ISSN: 2721-6136 (Online)

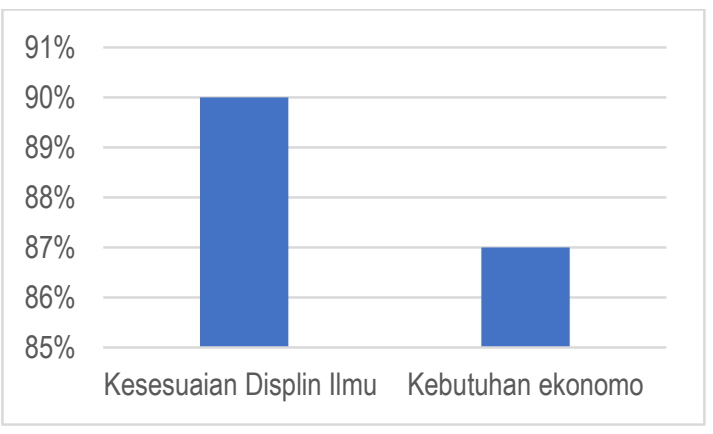

Gambar. 4 Grafik Faktor Pembelajaran Era 4.0

Pembentukan kebijakan ini merupakan kesepakatan bersama dari para guru terdahulu yang melihat bahwa terdapat beberapa anak berkebutuhan khusus yang kurang mampu berada di layanan kelas inklusi penuh. Menariknya, sistem sekolah ini membentuk keyakinan dan pengetahuan para subjek bahwa program inklusi adalah menempatkan anak berkebutuhan khusus di sekolah reguler dimana untuk memenuhi kebutuhan mereka dapat melalui berbagai layanan kelas yang ada.

\section{Diskusi Temuan}

Dalam Pengabdian Workshop On Implementation Of Learning On Disability Teaching In The Era Of Industrial Revolution 4.0 yang dilaksanakan ini ditemukan bahwa seluruh faktor yang bersumber dari guru, siswa, dan lingkungan pendidikan saling berhubungan satu sama lain. Namun, ditemukan perbedaan antara penemuan dalam penelitian ini dengan penemuan dalam penelitian terdahulu. Pertama, berdasarkan faktor siswa, Avramidis dan Norwich (2002) menemukan bahwa sikap guru dipengaruhi oleh jenis hambatan yang dimiliki anak berkebutuhan khusus, sedangkan dalam penelitian ini sikap guru lebih dipengaruhi oleh kondisi keparahan anak berkebutuhan khusus apapun jenis hambatannya. Peneliti menemukan bahwa guru lebih mendukung program inklusi untuk anak berkebutuhan khusus yang telah mampu bersekolah dan mengikuti pelajaran, sedangkan untuk anak berkebutuhan khusus yang kurang mampu mengikuti pelajaran diperlukan pendamping dalam belajar dan terapis untuk mempermudah guru menangani mereka.

Kedua, berdasarkan faktor guru dalam penelitian ini ditemukan berbagai faktor yaitu tipe guru, tingkat kelas, latar belakang, pendidikan, latar belakang guru, pengalaman mengajar, pengalaman kontak dengan anak berkebutuhan khusus, keyakinan guru, pandangan sosio-politik, pelatihan, pengetahuan, kebutuhan belajar guru, gender, dan empati. Dalam laporan ini terdapat faktor baru yang belum ada pada penelitian sebelumnya, yaitu faktor latar belakang guru, pengetahuan, kebutuhan belajar guru, dan empati. Faktor latar belakang guru ini merupakan faktor yang menunjukan alasan uru untuk 
bekerja sebagai guru di sekolah inklusi. Faktor ini cukup penting karena menjadi motivasi dasar guru untuk menunjukan sikap positif atau negatif terhadap pendidikan inklusi dan anak berkebutuhan khusus. Faktor pengetahuan yang ditemukan dalam penelitian ini memiliki kaitan dengan faktor keyakinan guru, latar belakang pendidikan, dan pelatihan. Faktor pengetahuan ini merupakan pemahaman guru terhadap konsep inklusi yang dapat berdampak pada praktek mengajar guru di kelas. Lebih lanjut lagi, faktor pengetahuan tersebut juga memunculkan faktor baru lagi yaitu faktor kebutuhan belajar guru yang menunjukan bahwa guru yang mau menerima program pendidikan inklusi di sekolah memiliki keinginan untuk menambah pengetahuan mengenai pendidikan inklusi dan anak berkebutuhan khusus. Faktor lain yang ditemukan dapat mempengaruhi sikap guru terhadap pendidikan inklusi dalam penelitian ini adalah faktor empati. Faktor empati merupakan faktor perasaan yang dimiliki oleh guru terutama terhadap anak berkebutuhan khusus. Ketika seorang guru memiliki empati kepada anak berkebutuhan khusus maka guru tersebut memperhatikan dan berusaha untuk menerima keadaan anak berkebutuhan khusus.

Ketiga, faktor lingkungan pendidikan yang melihat berbagai dukungan yang diterima guru untuk menunjang kegiatan belajar dan mengajar di sekolah inklusi. Faktor lingkungan pendidikan ini terdiri dari dukungan sumber daya, dukungan orang tua dan keluarga, serta sistem sekolah. Sistem sekolah merupakan faktor baru yang ditemukan dalam penelitian ini yang belum ditemukan dalam penelitian sebelumnya. Sistem sekolah menjadi penting dalam mempengaruhi sikap guru terhadap pendidikan inklusi karena guru akan merubah keyakinannya terhadap pendidikan inklusi menjadi sesuai dengan sistem yang berlaku di sekolah. Lebih lanjut lagi, guru dengan latar belakang pendidikan bukan di bidang Pendidikan Luar Biasa dan pengetahuan yang sedikit mengenai pendidikan inklusi akan merasa bahwa program pendidikan inklusi yang diterapkan di sekolah merupakan program yang paling tepat untuk diterapkan.

Sikap guru terhadap pendidikan inklusi yang muncul dalam penelitian ini berupa sikap positif dan negatif. Sikap positif dalam penelitian ini ditunjukan melalui penerimaan guru terhadap kehadiran anak berkebutuhan khusus di dalam kelas yang diajar, pandangan bahwa semua anak memiliki karakteristik dan kebutuhan masing-masing, serta harapan dan dukungan terhadap inklusi. Sikap negatif ditunjukan melalui kurang mendukungnya guru terhadap penempatan anak berkebutuhan khusus di kelas inklusi penuh, serta pandangan guru yang negatif terhadap kemampuan anak berkebutuhan khusus.

\section{Kesimpulan}

Sikap dan tingkat pemahaman guru terhadap pendidikan inklusi yang muncul dalam laporan ini berupa sikap positif yaitu sikap menerima terhadap pendidikan inklusi dan sikap negatif yaitu sikap 
GANDRUNG: Jurnal Pengabdian Kepada Masyarakat ISSN: 2721-6136 (Online)

menolak terhadap pendidikan inklusi. Faktor yang muncul dalam penelitian ini, yaitu pertama, faktor guru yang terdiri dari latar belakang guru, pandangan terhadap anak berkebutuhan khusus, tipe guru, tingkat kelas, keyakinan guru, pandangan sosio-politik, empati guru, dan gender. Kedua, faktor pengalaman yang terdiri dari pengalaman mengajar anak berkebutuhan khusus dan pengalaman kontak dengan anak berkebutuhan khusus. Ketiga, faktor pengetahuan yang terdiri dari latar belakang pendidikan guru, pelatihan, pengetahuan, dan kebutuhan belajar guru. Keempat, faktor lingkungan pendidikan yang terdiri dari dukungan sumber daya, dukungan orang tua dan keluarga, dan sistem sekolah

\section{Daftar Referensi}

Adi, R., \& Muhamad, S. T. (2020). Technology Innovation and Learning Media in Industrial Revolution Era 4.0 ( Blended Learning ) in Physical Education. UHAMKA, 120-122.

Anjar, F., Laksono, T., \& Soedirman, U. J. (2020). Penerapan Adaptasi Kebiasaan Baru pada Era Pandemi Virus Corona 19 di Berbagai Sektor Pendidikan (Issue December).

Fathurrahman, A., Sumardi, Yusuf, A. E., \& Harjianto, S. (2019). Peningkatan Efektivtas Pembelajaran Melalui Peningkatan Kompetensi Pedagogik dan Teamwork. Jurnal Manajemen Pendidikan, 7(2), 1-14. https://doi.org/10.16043/j.cnki.cfs.2019.15.130

Gall, M. D., Gall, J. P., \& Borg, W. R. (2003). Epdf.Pub_Educational-Research-an-Introduction-7ThEdition.Pdf.

Sumantri, A., \& Neldi, H. (2019). Profil Pelaksanaan Pembelajaran PJOK di SD Gugus 1 Kecamatan Bintan Timur. JPO Jurnal Pendidikan Dan Olahraga, 2(1), 160-164. jpdo@ppj.unp.ac.id

Wijayanto, A., Yunis, S., Ari, B., Kurniawan, W., Rahadian, A., Amiq, F., lka, A., Joan, N., Andrianto, R., \& Baun, A. (n.d.). eBook B Strategi Pembelajaran PJKR selama Covid19.

Wisman, Y. (2017). Komunikasi Efektif Dalam Dunia Pendidikan. Jurnal Nomosleca, 3(2), 646-654. https://doi.org/10.26905/nomosleca.v3i2.2039

Yuniarto, A., Supriyadi, S., \& Sudjana, I. N. (2018). Pengembangan Media Pembelajaran Berbasis Mobile Learning Teknik Dasar Dan Peraturan Permainan Futsal. JP.JOK (Jurnal Pendidikan Jasmani, Olahraga Dan Kesehatan), 2(1), 51-62. https://doi.org/10.33503/jpjok.v2i1.188 